\title{
DEVELOPING PRACTICAL GUIDELINES OF TEACHING WRITING USING COOPERATIVE INTEGRATED READING AND COMPOSITION
}

\author{
Ashri Shollina ${ }^{l}$
}

Dewi Rochsantiningsih ${ }^{2}$

Joko Nurkamto ${ }^{3}$

${ }^{1}$ English Education Department, Muhammadiyah Islamic Education Institute of Tanjung redeb, Berau, Indonesia, ashri82@gmail.com

${ }^{2}$ English Education Department, Graduate School of Sebelas Maret University, Surakarta, Indonesia

${ }^{3}$ English Education Department, Graduate School of Sebelas Maret University, Surakarta, Indonesia

\begin{abstract}
Cooperative integrated reading and composition (CIRC) technique gives the opportunities for the students to increase language skills, especially applicability of reading activities and composition writing techniques. The absence of a guideline of teaching writing using certain technique results a less effective process of teaching writing. Thus, this research and development study was aimed to investigate the quality of the existing guidelines of writing in junior high school and the development of the practical guidelines of teaching writing in SMPN of Karanganyar Central Java using Cooperative Integrated Reading and Composition. This research was conducted through two stages; exploration stage and product development stage. The finding of the exploration stage was obtained through several techniques like interview, observation, document analysis and questionnaire distribution which revealed that there was no certain writing guideline used to teach. The teachers used textbook, syllabus and lesson plan as the guidance of teaching writing. Thus, the writing guideline should be developed by considering the need of the teacher and the students. The guideline prototype was developed by considering some aspects. It contained theoretical theories of writing, CIRC and teaching writing to Junior High School and the implementation of teaching writing of descriptive, recount, and narrative texts. Then, it had been validated by the expert and tried out thrice in one class of eighth graders of SMPN in Karanganyar Central Java. Through focus group discussion, the guideline prototype was changed and revised to be the final draft of writing guideline. Therefore, through the stages, it could be concluded that the practical guideline was feasible to be used by the teachers to teach writing to junior high school students.
\end{abstract}

Keywords: CIRC, guideline, writing, research and development study 


\section{Introduction}

\subsection{Writing}

Writing is one of the language skills that should be demanded by the students. This skill will help them to express their thoughts, feelings, ideas and knowledge in written form. Nunan (2003) defines that writing is the process of thinking to invent ideas, thinking about how to express it into good writing, and arranging the ideas into statement and paragraph clearly. Meyers (2005) states that writing is an action - a process of discovering and organizing ideas, putting them on paper, reshaping, and revising them. While Hyland (2004) states that writing is a sociocognitive activity that involves skills in planning and drafting, as well as knowledge of language, contexts, and audiences. It means that in creating good writing, writers need to employ their thought. They also need knowledge about how to express their ideas in written form.

To produce a good writing, it needs a long process and practices before it becomes a final product. Whereas, writing skill can develop rapidly when students' concerns and interests are acknowledged, when they are given numerous opportunities to write, and when they are encouraged to become participants in a community writers.

\subsection{Cooperative Learning}

Richards and Rodgers (2001) define Cooperative Learning as an approach to teaching that makes maximum use of cooperative activities involving pairs and small groups of learners in the classroom. According to Barkley, et. al. (2005) Cooperative Learning is the instructional use of small groups so that students work together to maximize their own and each others' learning. Cooperative learning provides a perfect opportunity for them to interact and collaborate with friends and other young people who are likely to become friends. It is an effective teaching strategy in which the students work in small teams using a variety of learning activities to enhance their understanding of a lesson. By doing such activities, each student is expected to be responsible not only for his/her understanding but also for helping teammates.

\subsubsection{Cooperative Integrated Reading and Composition (CIRC)}

However, there are too many techniques described with a little of explanation in application in the teaching learning process. Moreover, knowing only the techniques does not guarantee they know how to apply it in the classroom and decide the right skill to be taught. Thus, it is needed to make a guidance of using cooperative learning which focuses on certain skill. As the students' need to learn about writing which is involving them to be highly participated in learning process, cooperative learning provides cooperative integrated reading and composition (CIRC) technique that is designed to develop writing by giving the opportunities to increase language skills and especially applicability of composition writing techniques. 
Madden (2004) clearly defines Cooperative Integrated Reading and Composition (CIRC) as a school-based program that targets reading, writing, and language arts in grades 2 through 6. As quoted by Bancroft (2010), CIRC puts the students to work in cooperative teams on activities in reading comprehension, vocabulary, decoding, and spelling that are coordinated with their reading group instruction their basal readers. CIRC requires the students to take apart a lot in the teaching learning process. Through sequence activities, the students are lead to reach the goal of writing skill that is to be a good writer. Teaching writing is unique; it benefits both teacher and student, serving as communication vehicle, assessment tool, and intellectual exercise. Writing is a complex process, and most of the research literature recognizes the difficulties possessed by the students. Richards and Renandya (2010) suggest free variation of writing stages in writing class such as planing, drafting, responding, revising, editing, evaluating, and post-writing. While Nation (2009) lists seven sub processes in writing, they are; considering the goals, having a model of the reader, gathering ideas, organising ideas, turning ideas into written text, reviewing and editing.

\subsection{Practical Guideline}

Actually, the existing guidance of using cooperative learning is quite enough to be learned. Instructional design defined as guidelines or sets of strategies on which the approaches to teaching by instructors are based (Qureshi, 2004; Braxton et al., 1995). While Grenville (2001) simply states that a plan is a guide. Guideline is a detailed plan or explanation to guide in setting standards or determining a course of action. In line with this, Piskurich, (2000) views instructional design or guidelines as a set of rules or procedures for creating training that does what is supposed to do (determining the goals of the training), while other procedures deal with letting the participant knows what those goals are.

\section{Method}

The research used a research and development $(\mathrm{R} \& \mathrm{D})$ design. The product developed in this study was practical guidelines of teaching writing for the eighth graders of Junior High School. In developing it, the use of CIRC was explored much more.

\subsection{Respondents}

In the exploration stage, the passive participant classroom observation was conducted in the writing class by Teacher SUN and Teacher DE. In the free-guided interview, some questions related to the needed information in developing the product were given to Teacher SUP, Teacher SUN and Teacher DE. In the need analysis stage, closed questionnaires were given to students (teacher SUN and teacher DE class) and 12 english teachers of POKJA V Karanganyar Tengah to find out the needs about the guideline.

\subsection{Instruments}

This research used some various instruments in classroom observation, teacher's interview and questionnaire of need analysis, and in-depth interview guidelines to the teachers. Some instuments were also constructed to analyze the syllabus, lesson plan, and textbook used by the teacher before developing the product. This researh used an instrument 
to validate the writing guideline. Then to try out the product, a form of instument was also used as the observation guide of the writing class.

\subsection{Reasearch Procedures of Research and Development}

There are two stages in this research; (1) exploration and (2) product development. Exploration stage has several steps namely; literature review, field study, need analysis and developing prototype. The product development stage has several steps namely; developing draft, validation of the guideline, try out, and the developing of the final draft of the guideline. Each of stage has different steps and purpose.

Table 1. Data Analysis of Developing Writing Guidelines Using CIRC

\begin{tabular}{|c|c|c|c|}
\hline \multirow{11}{*}{ Exploration Stage } & Objective & & $\begin{array}{l}\text { To find out the existing guidelines, the condition } \\
\text { of writing and teaching learning process in Junior } \\
\text { high school }\end{array}$ \\
\hline & \multirow{2}{*}{\multicolumn{2}{|c|}{ Source of Data }} & English teachers \\
\hline & & & Documents \\
\hline & & & Interview \\
\hline & Technique & \multirow{5}{*}{ Data } & Observation \\
\hline & Collecting & & Document Analysis \\
\hline & & & Questionnaire \\
\hline & \multirow{2}{*}{ Data } & & Description of: the existing guidelines, \\
\hline & & & Syllabus, Lesson plan, textbook \\
\hline & $\begin{array}{l}\text { Technique } \\
\text { Analyzing }\end{array}$ & \multirow[t]{2}{*}{ Data } & Descriptive Qualitative Analysis \\
\hline & Output & & $\begin{array}{l}\text { The description of the existing guidelines and } \\
\text { prototype }\end{array}$ \\
\hline \multirow{16}{*}{$\begin{array}{l}\text { Product } \\
\text { Development }\end{array}$} & \multirow{3}{*}{\multicolumn{2}{|c|}{ Objective }} & To create a writing guideline using CIRC \\
\hline & & & To create the writing guideline using CIRC for \\
\hline & & & Eighth graders of Junior High School \\
\hline & \multirow{4}{*}{\multicolumn{2}{|c|}{ Source of Data }} & English Teachers \\
\hline & & & Expert \\
\hline & & & English Teachers \\
\hline & & & Students \\
\hline & \multirow{4}{*}{$\begin{array}{l}\text { Technique } \\
\text { Collecting }\end{array}$} & \multirow{4}{*}{ Data } & Observation \\
\hline & & & Interview \\
\hline & & & Documents \\
\hline & & & Questionnaire \\
\hline & \multirow{2}{*}{ Data } & \multirow{5}{*}{ Data } & The writing guideline \\
\hline & & & The writing teaching learning process \\
\hline & Technique & & Descriptive Qualitative Analysis \\
\hline & Analysing & & Descriptive Statistics \\
\hline & Output & & $\begin{array}{l}\text { The writing guideline using CIRC for Eighth } \\
\text { graders of Junior High School }\end{array}$ \\
\hline
\end{tabular}

\section{Finding and Discussion}

\subsection{Reasearch Questions}


The problems of the study stated as follows:

1. How is the quality of the existing guidelines of writing in junior high school?

2. What is the development of the practical guidelines of teaching writing in SMPN 4 Karanganyar using Cooperative Integrated Reading and Composition?

\subsubsection{The quality of the existing guidelines of teaching writing in Junior High School}

The interview to teachers who participated in this research showed that they did not have any guideline to teach writing for junior high school students. The teachers mostly used textbook entitled "English in Focus" to teach the students. The textbook was also accompanied by Students Work Sheets or (LKS) such as "Solusi". Other books used by the teachers were "Real Time" and "Lets Talk". However, "English in Focus" was mostly used both by the teachers and students. From the interview, teachers revealed that "English in Focus": (1) was available in the library, (2) the stocks were plenty that the students can get one also, and (3) the contents were relevant to the curriculum.

The interview result referred to the use of textbook as guidance in teaching writing. As mentioned before, all of skills covered in the book are integrated (listening, speaking, reading and writing). The textbook used, entitled English in Focus carrying some materials. The analysis of textbook was based on the Cunningsworth (1995) model that based on: (1) impressionistic overview and (2) in-depth analysis evaluation. The materials of writing begin with modelling of text followed by the explanation of the materials. There are no activities which study carefully about accuracy of writing. The learning focus emphasize on the materials of language function, genre of text and grammar. However, writing activities in the textbook do not represent suitable activities in terms of amount of neither accuracy aspect nor the organization of longer places of writing. All of the activities and materials provided within the textbook are used by the teachers to teach writing and became their guidance also.

The teachers were going along also with the syllabus and lesson plan they made before. The syllabus and lesson plan were based on the standard competence and basic competence of the existing curriculum. Writing skill is a one of skills taught integrated to the students. It was described in the syllabus and lesson plan which had a certain part of writing skill. The syllabus completed with the lesson plan which were consisting materials, methods, media, and teaching learning procedures to guide the teachers in teaching all of skills, and so writing skill.

Based on the textbook analysis, it can be concluded that provides many exercises and texts to students but no clear application of using certain technique in teaching writing. Those findings came together with the result of questionnaire which is distributed to the twelve English teachers from six schools in POKJA (Kelompok Kerja) V Karanganyar Tengah. It came to the result that the writing guideline is needed to be developed in order to help teachers in enhancing the students' writing competence. They also did not vary their teaching technique in classroom well. There are a few teachers who use certain technique such as Cooperative learning in teaching writing. However, most of them mentioned specific techniques such as lecturing, discussion, and question-answer that could be the sign of teacher-centred model in classroom. The findings, gave a picture that the writing guidelines would need to be developed carefully and systematically. To sum up the result of questionnaire, it is presented in table 2. 
Table 2. Questionnaire result of need analysis toward writing guidelines

\begin{tabular}{llll}
\hline Question & Total & Percentage & Criteria \\
\hline The use of writing guidelines & 12 & $100 \%$ & No \\
Writing guidelines used in teaching writing: & & & \\
Syllabus & 8 & $67 \%$ & \\
Lesson plan & 8 & $67 \%$ & \\
Students worksheet & 3 & $33 \%$ & \\
Textbook & 6 & $50 \%$ & Supportive \\
& 8 & $67 \%$ & \\
The use of learning set in teaching writing & & & \\
Technique used in teaching writing: & & & \\
Cooperative learning (CL) & 2 & $17 \%$ & \\
Integrated reading and writing & & & \\
Specific method & 2 & $17 \%$ & Good \\
& 8 & $67 \%$ & Do not understand \\
& 12 & $100 \%$ & Yes
\end{tabular}

Total number of respondent: 12 (English teachers of POKJA V Karanganyar Tengah)

The data obtained through exploration stage became the foundation of the next stage. The data gathered through some techniques revealed the need of the teacher and the students related to the importance of writing guideline in teaching learning process. There were three discussions resulted from the product development stage; the description of writing guideline prototype, try out of the guideline prototype and the last was the final draft of the guideline.

\subsubsection{The development of the practical guidelines of teaching writing}

\subsubsection{Product development stage}

The development of this guideline was based on the findings and need analysis in the exploration stage and some theoretical reviews. The development of this writing guideline was initiated by making syllabus and lesson plans for semester one and two of the eighth graders of junior high school. However, it was limited to the writing skill and only consists of the three genres taught to eighth graders i.e. descriptive, recount, and narrative text.

The syllabus made was based on Permendiknas paragraph 20 year 2005. Then the content of syllabus was elaborated to the lesson plans based on Permendiknas No. 41 year 2007. Since the content of this guideline was about three genres descriptive, recount, and narrative text, the teacher could also used the guideline to teach writing for the seventh and ninth graders of Junior High School. The seventh graders are taught two genres of text i.e. descriptive and procedures while the ninth graders are taught three texts i.e. procedures, report and narrative.

There are three parts explored further in this guideline after introduction section. Introduction section described the general information about the guideline. It presented the readers about the target user of the guideline, the background of developing the guideline, 
what is covered in the guideline, and a brief introduction about CIRC and cooperative learning. It is expected for the readers to build a theory based on principles of teaching learning using Cooperative Learning.

The topic of the first part was about CIRC. It explained more about the definition, concepts, teaching learning activities of CIRC and the reasons why it is suggested to use CIRC. The second part discussed teaching junior high school to write. It covered the definition, steps, types, and assessment in writing. Both parts provided information of the learning theories within the developing guideline. The last part was about the implementation of teaching writing using CIRC for descriptive, recount, and narrative texts. Basically, the activities of the three teaching texts were the same. However, because of the difference of the genre of texts, the teaching steps in writing process also different. Last but not least, this guideline attached some appendices; syllabus, lesson plan, and examples of text for all three texts. The content of the guideline was presented below in the table 3 .

Table 3. Content of Writing Guideline Using CIRC

\begin{tabular}{|c|c|c|}
\hline Part & Heading & Subheading \\
\hline & Introduction & $\begin{array}{l}\text { Who is this Guideline for? } \\
\text { What is this Guideline about? } \\
\text { What's in this Guideline that can Help You? } \\
\text { CIRC Method of Cooperative Learning } \\
\text { Review of Cooperative Learning }\end{array}$ \\
\hline Part One & $\begin{array}{l}\text { Cooperative Integrated Reading } \\
\text { and Composition }\end{array}$ & $\begin{array}{l}\text { What is CIRC? } \\
\text { Concepts of CIRC } \\
\text { Teaching Learning Activities of CIRC } \\
\text { Why Use CIRC? }\end{array}$ \\
\hline Part Two & $\begin{array}{l}\text { Teaching Junior High School to } \\
\text { Write }\end{array}$ & $\begin{array}{l}\text { Let's Learn to Write } \\
\text { How to Assess Writing Skill? } \\
\text { Types of Writing } \\
\text { Teaching Writing to Junior High School }\end{array}$ \\
\hline Part Three & $\begin{array}{l}\text { Smart Teaching Writing with } \\
\text { CIRC }\end{array}$ & $\begin{array}{l}\text { Teaching a Descriptive Text } \\
\text { Teaching a Recount Text } \\
\text { Teaching a Narrative Text }\end{array}$ \\
\hline Appendices & $\begin{array}{l}\text { Lesson Plans } \\
\text { Examples of Text }\end{array}$ & $\begin{array}{l}\text { Syllabus of Descriptive Text } \\
\text { Syllabus of Recount Text } \\
\text { Syllabus of Narrative Text } \\
\text { Lesson Plan of Descriptive Text } \\
\text { Lesson Plan of Recount Text } \\
\text { Lesson Plan of Narrative Text } \\
\text { Descriptive Text } \\
\text { Recount Text } \\
\text { Narrative Text }\end{array}$ \\
\hline
\end{tabular}

The guideline was developed based on some considerations. There were ten aspects to be considered which also used to evaluate the quality of the guideline by the expert. There were; (1) design, (2) objective, (3) language content, (4) skill, (5) topic, (6) methodology, (7) 
instruction, (8) learning procedure, (9) organization, and (10) teacher's book. The description of all aspects can be seen in the table 4 .

Table 4. The Aspects of the Developing Guideline

\begin{tabular}{|c|c|}
\hline Aspects & Criteria \\
\hline Design & It deals with the quality of cover and layout of the guideline \\
\hline Objective & $\begin{array}{l}\text { It deals with the availability of the Objectives and it represented the } \\
\text { overall content of the guideline }\end{array}$ \\
\hline \multirow[t]{2}{*}{ Language content } & $\begin{array}{l}\text { It deals with the appropriateness of the writer's writing style with } \\
\text { the language }\end{array}$ \\
\hline & $\begin{array}{l}\text { level (grammar and vocabulary) of teacher and students of Junior } \\
\text { High School }\end{array}$ \\
\hline Skill & $\begin{array}{l}\text { It deals with the quality of the presented writing skill (theory, } \\
\text { aspects, process) in the guideline }\end{array}$ \\
\hline Topic & $\begin{array}{l}\text { It deals with the appropriateness of the chosen topic and genres of } \\
\text { text with the language level of students of Junior High School }\end{array}$ \\
\hline Methodology & $\begin{array}{l}\text { It deals with the quality of the theoretical reviews used in classroom } \\
\text { teaching learning }\end{array}$ \\
\hline Instruction & It deals with the quality of the instruction within the guideline \\
\hline $\begin{array}{c}\text { Learning } \\
\text { Procedures }\end{array}$ & $\begin{array}{l}\text { It deals with the quality of the explanation of learning procedures } \\
\text { applied in classroom }\end{array}$ \\
\hline Organization & It deals with the systematic content of the guideline \\
\hline Teacher' Book & $\begin{array}{l}\text { It deals with the effectiveness the guideline as a complimentary of } \\
\text { teaching sets }\end{array}$ \\
\hline
\end{tabular}

The developing guideline has passed through the process of revision and consultation to the expert. Therefore, when it was validated, the expert gave good score toward the developing guideline. The total score from all of the aspects was 34 in which it belonged to the category of excellent development.

The second stage of product development was trying out the draft of writing guideline. The try out was conducted to know how was the implementation of writing guideline in the classroom by the teacher. The tryout of the product was conducted in one class of the eighth grade in SMP Karanganyar. Try out of the writing guideline was conducted for thrice involving the teacher, the expert that was the chairperson of POKJA V Karanganyar Tengah, and the researcher as the observer of classroom teaching learning process. 
The Implementation stage was conducted to see the feasibility of the product in terms of products' practicality by measuring up the response given by the teacher and students. During the implementation, the researcher observed the classroom activities in which the technique was passive classroom observation. Then, the focus group discussion (FGD) was conducted to reflect the implementation of the guideline to teach writing by the researcher, teacher, students, and the expert involved.

This discussion was aimed to evaluate the implementation and the improvement of the guideline for the second try out and so on till the third try out. The implementation was over when the product was considered as optimal and consistent as possible. At the end of the try out, the teacher was distributed questionnaire. The teacher gave their response about the practical guidelines using CIRC to teach writing. While the response given by the students, showed the impact of being taught using the guidelines.

In order to know the students' response toward the implementation of CIRC in learning writing provided in the guideline, they were given a questionnaire. There were fifteen questions that represented three aspects; activities in CIRC, cooperative skill, and writing improvement. The result showed that there was $76 \%$ students enjoyed the way the teacher taught writing class using CIRC. The students' response in cooperative skill was 78\%, showing that most of the students prefer working in a group to individual. Then, there was $79 \%$ students who thought well of their writing improvement by applying CIRC. All of those aspects were classified to the excellent that indicated the students' response toward the implementation of CIRC in writing class provided in the guideline was good. The result of the questionnaire of the students' response could be seen below in table 5.

Table 5. Questionnaire Result of Students' Response

\begin{tabular}{llll}
\hline Aspects & Students' Score & Percentage & Criteria \\
\hline Activities in CIRC & 548 & $76 \%$ & Excellent \\
\hline Cooperative Skill & 560 & $78 \%$ & Excellent \\
\hline Writing Improvement & 567 & $79 \%$ & Excellent
\end{tabular}

The teacher was also given a questionnaire to know the teacher's response toward the use of writing guideline by applying CIRC. From the result of the questionnaire, it could be seen that the teacher responded very well which achieve total score 54 from the maximum score 60. Therefore, it could be concluded that the teacher's response toward the use of the guideline in teaching writing was categorized as excellent. This developing writing guideline was very helpful for the teacher in teaching writing and could be the complement of the existing textbook and sudents' worksheet. The teacher suggested that there should be another writing guideline that explores how to teach other genres or short functional texts other than descriptive, recount and narrative.

Try out of the writing guidelines that has been conducted in class should be fully completed by examining the finding of try out. The result of this stage is the final product of 
writing guidelines using CIRC for the eighth graders of Junior High School. During the try out, the guideline had been changed and revised. The revisions were based on findings in FGD, result of the questionnaire given to the students and the teacher. Therefore, the guideline was developed based on the need of the students and the teacher. There were some differences from the guideline before to the final draft. The final draft of writing guidelines consisted of theoretical reviews and procedures systematically based on the need analysis conducted in the field study.Thus, the overall revisions changed the guideline into a final draft. The changes after trying out for thrice were resumed briefly in the table 6 below.

Table 6. Revisions during the Try-Out I-III

\begin{tabular}{|c|c|}
\hline $\begin{array}{c}\text { Try Out } \\
\text { I }\end{array}$ & $\begin{array}{l}\text { - Added information about how the group members formed. The group } \\
\text { members formed based on heterogeneous students } \\
\text { - Added information about technique in predicting vocabularies using } \\
\text { headword instead of providing it directly } \\
\text { - Revised the information of the group members from 4-5 students to 3-4 } \\
\text { students. }\end{array}$ \\
\hline $\begin{array}{c}\text { Try Out } \\
\text { II }\end{array}$ & $\begin{array}{l}\text { - Changed the assessment checklist of Recount and Narrative text in English to } \\
\text { Bahasa Indonesia } \\
\text { - Added the materials of structures involved in descriptive, recount, and } \\
\text { narrative text. }\end{array}$ \\
\hline $\begin{array}{c}\text { Try Out } \\
\text { III }\end{array}$ & $\begin{array}{l}\text { - Revised a grammatical error of a sentence in part of predicted outline in } \\
\text { recount text } \\
\text { - Revised the information of CIRC accomplishment in two meetings } \\
\text { - Added information of the way appreciating the students }\end{array}$ \\
\hline
\end{tabular}

Those revisions and changes gave a good impact to the completion of the final draft. Through the process of this research, there were some strengths and weaknesses of the developing guideline viewed from the researcher's point of view. The teacher felt excited to apply CIRC in classroom because the teacher only know Jigsaw as one of technique in Cooperative Learning. Moreover, the teacher found that the students were good in following the writing class by using CIRC. Both strengths and weaknesses described briefly in the table 7 below.

Table 7. Strentghs and Weaknesses of the Guideline

\begin{tabular}{|c|c|}
\hline Strengths & Weaknesses \\
\hline $\begin{array}{l}\text { - The guideline was based on theoretical } \\
\text { reviews that facilitate the teacher in } \\
\text { understanding the concepts before the } \\
\text { implementation } \\
\text { - The implementation of writing class was } \\
\text { presented in a clear instruction and } \\
\text { understanding }\end{array}$ & $\begin{array}{l}\text { - The skill focused in the guideline was only } \\
\text { for writing skill, it would be better to develop } \\
\text { other guidelines in different skills } \\
\text { - The development of the syllabus and lesson } \\
\text { plan were not based on the new curriculum, } \\
\text { that is curriculum } 2013 \\
\text { - The examples of the texts were not completed } \\
\text { with the questions. Tthe teachers are }\end{array}$ \\
\hline
\end{tabular}


- The guideline was completed with the syllabus, lesson plan and the examples of the texts

- The guideline was developed to meet both the teacher and the students' need challenged to elaborate the questions based on the students' ability

- The material of the guideline was limited to three texts for the eight graders of Junior High School

\section{Conclusion}

Based on the finding from the stages of $R \& D$ about developing practical guideline of teaching writing using CIRC for Junior High School, conducted in SMPN in Karanganyar, there are two conclusions formulated. First, it is about the quality of the existing guidelines of writing in Junior High School. Through exploration stage, it found that there was no certain writing guideline used in Junior High School. The data was obtained from the interview to the teachers and strongly supported by the result of questionnaire from twelve teachers of six schools in POKJA V Karanganyar Tengah. Most of the teachers used syllabus, lesson plan, and textbook, to be the guidance in teaching writing.

Based on the analysis of the textbook, it revealed that the textbook did less support the teacher to develop the students' writing skill effectively. It was because the textbook used a general method that was task based approach to teach all skills (listening, speaking, reading and writing). Besides, the finding of the classroom observation showed that the students were less attractive to learn how to write since the teacher taught them in traditional approach. In addition, though syllabus and lesson plan made by the teacher followed the components of syllabus and lesson plan by Permendiknas, in classroom observation, the teacher did not use the syllabus and lesson plan effectively.

There was no certain method used to teach writing explained in the syllabus and lesson plan so the teaching learning process did not work well. The conclusion was the quality of teaching sets used by the teacher as the guidance in teaching writing was less supportive to the improvement of the students' writing skill.

Second, it was about the development of the practical guidelines of teaching writing in SMPN in Karanganyar using Cooperative Integrated Reading and Composition. Basically, there are two main points contained in the guideline, the theoretical reviews and the classroom implementation. Through the process of consultations and revisions from the experts and consultants, it was revised some concepts provided in the guideline. The concepts or the theoretical reviews should be explained concisely and briefly so that the teacher could easily understand the content of the guideline.

The developing guideline was tried out after the process of expert validating. It was tried out for thrice and was evaluated through the FGD by the teacher, the expert, the students, and the researcher itself. Those FGD produced some revisions on the guideline. Thus, the final draft of the developing guideline was based on the teacher and the students' need and it is feasible to be used by the teacher in teaching writing. The existence of this guideline could be a complimentary of other teaching sets that support the students to improve their writing skill. 


\section{Acknowledgments}

My gratitude goes to Mrs. Dewi Rochsantiningsih, and Mr. Joko Nurkamto, for their kind and helpful improvement to this research. Furthermore, I also gratefully thank to Mr. Abdul Asib for the invaluable guidance and considerable help in validating the product. Hopefully, this research and the developing guideline could give positive contribution to the implementation of teaching writing to Junior High School students. The researcher woud accept every comment and suggestion gratefully.

\section{References}

Bancroft, Briana L. (2010). Enhancing student achievement through cooperative learning at the elementary level.Retrieved from http://www.nmu.edu/sites/Drupal Education/files/UserFiles/Files/PreDrupal/SiteSections/Students/GradPapers/Projects/Bancroft_Briana_MP.pdf.

Barkley, E., Cross, P., \& Major, C. (2005). Collaborative learning techniques: a book for college faculty. SanFransisco: Jossey-Bass.

Cunningsworth, Alan. (1995). Choosing your coursebook. Oxford: Heneimann.

Grenville, Kate. (2001). Writing from start to finish: a sixth-step guide. New South Wales: Allen \&Unwin.

Hyland, Ken. (2004). Genre \& second language writing. New York: The University of Michigan Press.

Madden, Nancy. (2004). Cooperative Integrated Reading \& Composition. Retrieved fromhttp://www.Promisingpractices.net/program.asp?Programid=142.

Nation, I.S.P. (2009). Teaching ESL/EFL reading \& writing. New York: Routledge

Nunan, David. (1995). Language teaching methodology; a textbook for teachers. London: Prentice Hall Europe.

Piskurich, George M. (2000). Rapid instructional design: learning id fast \& right. San Fransisco: Jossey-Bass Pfeiffer.

Qureshi, Elena. (2004). Instructional design models.Retrieved from http://web2.uwindsor.ca/courses/edfac/morton/instructional_design.htm.

Richards, Jack. C. \& Renandya, W. A. (2010). Methodology in language teaching(an anthology of current practice). New York: Cambridge University Press.

Richards, Jack C \& Rodgers, Theodore S. (2001).Approaches \& methods in language teaching (2nd edition). Melbourne: Cambridge University Press.

Robb, Laura. (2012). Practical units for teaching middle school writer: teachingguide.Portsmouth, $\mathrm{NH}$ :Heinemann. 


\section{Appendices}

\section{Appendix 1}

Instrument of Teacher's Interview and Questionnaire of Need Analysis

- Protocol of IN-DEPTH INTERVIEW toward English teachers Grade VIII

Goals : a. Examining the existing learning condition

b. Examining the existing writing guideline in classroom

c. Examining the application of CIRC (Cooperative Integrated Reading and Coposition)

- Questionnaire of Need Analysis toward the Development of Writing Guidelines Using Cooperative Integrated Reading and Composition (CIRC) for the teachers in Junior High School

Goals

: a. Examining the existing writing guideline in classroom

b. Examining the application of CIRC (Cooperative Integrated Reading and Coposition)

c. Doing need analysis toward the writing guidelines using CIRC

In-Depth Interview Guidelines

Pembelajaran Writing

A. Tujuan dan Perangkat Pembelajaran

1. Apakah tujuan dari pembelajaran writing?

2. Bagaimana respon siswa terhadap pembelajaran writing?

3. Bagaimana hasil dari pembelajaran writing di kelas?

4. Apakah anda selalu menyiapkan mapping, silabus dan RPP sebelum mengajar?

5. Apakah perangkat pembelajaran tersebut anda buat sendiri?

B. Teknik atau Metode

6. Metode atau teknik pembelajaran apa yang anda pernah terapkan di kelas?

7. Seberapa efektif metode pembelajaran tersebut?

8. Bagaimana respon siswa dan hasil writing dari metode atau teknik tersebut?

9. Adakah kendala yang dihadapi dalam penerapan metode atau teknik tersebut?

C. Media

10. Apalah anda sering menggunakan media dalam prosess pembelajaran?

11. Media apa saja yang pernah digunakan di kelas?

12. Seberapa efektif media pembelajaran tersebut?

13. Bagaimana media tersebut digunakan di kelas?

D. Materi

14. Apakah anda memilih materi yang kontekstual dalam mengajar?

15. Darimana anda mengambil materi tersebut?

16. Apakah anda sering memberikan tugas menulis kepada siswa? Dalam bentuk apa?

17. Bagaimanakah hasilnya?

18. Apakah anda menggunakan buku panduan dalam menulis?

19. Jika iya, buku panduan apa yang digunakan?

20. Jika tidak, lalu apa yang dijadikan sebagai panduan dalam menulis?

E. Feedback dan Motivasi

21. Apakah anda selalu memberikan feedback kepada siswa? Dalam bentuk apa?

22. Lalu, apakah anda juga memotivasi siwa supaya tetap menulis?

23. Apakah hal tersebut menunjukkan hal yang lebih baik?

Penerapan Kooperatif Learning CIRC

A. Group Work

24. Apalah anda sering mengunakan model pembelajaran Kooperatif Learning?

25. Metode Kooperatif Learning apa saja yang pernah anda terapkan di kelas?

26. Apakah anda pernah menerapkan metode CIRC?

27. Bagaimanakah dampak dari pembelajaran Kooperatif Learning tersebut?

28. Bagaimanakah tanggapan siswa?

B. Kegiatan dan tugas yang terorganisir

29. Bagaimanakah kegiatan tersebut dilaksanakan di kelas?

30. Kegiatan tersebut membutuhkan berapa kali pertemuan kelas? 
31. Bagaimanakah tugas writing yang diberikan kepada siswa?

32. Dengan metode tersebut, apakah hasil writing siswa menjadi lebih baik?

C. Informasi atau pengetahuan

33. Apakah anda selalu memberikan modelling terhadap siswa?

34. Apakah anda menggunakan buku panduan khusus yang digunakan dalam pembelajaran writing dengan metode Kooperatif Learning?

35. Apakah menurut anda buku panduan tersebut sangat dibutuhkan dalam pembelajaran writing? Mengapa?

D. Memberikan bimbingan

36. Bagaimanakah anda menjalankan peran sebagai guru di kelas?

37. Kegiatan bimbingan apa yang diberikan kepada siswa?

KUESENER ANALISIS KEBUTUHAN PENGEMBANGAN WRITING GUIDELINES MENGGUNAKAN TEKNIK COOPERATIVE INTGRATED READING AND COMPOSITION (CIRC) UNTUK GURU BAHASA INGGRIS KELAS VIII

$\begin{array}{ll}\text { Nama } & : \\ \text { Alamat } & : \\ \text { No. Hp } & : \\ \text { Pokja } & : \\ \text { Asal Sekolah } & \text { : }\end{array}$

Di bawah ini saya sampaikan sejumlah pernyataan/pertanyaan yang berkaitan dengan penyelenggaraan writing guidelines menggunakan teknik CIRC di kelas yang Bapak/Ibu ampu. Mohon Bapak/Ibu mengisi pernyataan/pertanyaan di bawah ini berdasarkan kondisi yang sebenarnya. Atas partisipasi Bapak/lbu, kami ucapkan terimakasih.

1. Dalam mengajar Writing di kelas, apakah Bapak/Ibu menggunakan Guidelines atau buku panduan tertentu? (beri tanda $x$ )

$$
\begin{array}{ll}
\text { a. Ya } & \text { b. Tidak }
\end{array}
$$

2. Bila Ya, guidelines atau buku panduan apa yang digunakan?

Judul

Pengarang

Penerbit/Tahun Terbit:

3. Apakah guidelines tersebut memenuhi aspek dibawah ini? (beri tanda $\sqrt{ }$ ) Berlandaskan teori tertentu

$\square$ Berisi sekumpulan langkah-langkah penerapannya di kelas

Berisi usulan tindakan di kelas

Lain-lain:

4. Apakah guidelines tersebut mendukung Bapak/Ibu dalam mengajar writing di kelas? (beri tanda $x$ ) a. Sangat mendukung $b$. Mendukung c. Kurang mendukung d.Tidak mendukung

5. Bila Tidak, apa yang dijadikan sebagai panduan dalam pembelajaran writing di kelas? (beri tanda $x$, jawaban boleh lebih dari satu)
a. Silabus
b. RPP
c. LKS
d. Buku Teks

6. Silabus dan RPP yang digunakan dalam pembelajaran dibuat oleh:

a. Masing-masing guru pengampu kelas b. Guru Bahasa Inggris Sekol

c. Guru se-Pokja/MGMP

$$
\text { d.Lain-lain: .......... }
$$

7. Apakah perangkat pembelajaran tersebut menunjang keberhasilan siswa dalam writing? (beri tanda $x$ ) Silabus: a. Sangat mendukung b. Mendukung c. Kurang mendukung

d. Tidak mendukung

RPP : a. Sangat mendukung b. Mendukung c. Kurang mendukung

d. Tidak mendukung

LKS : a. Sangat mendukung b. Mendukung c. Kurang mendukung

d. Tidak mendukung

Buku Teks: a. Sangat mendukung b. Mendukung c. Kurang mendukung

d. Tidak mendukung 
8. Bila menggunakan buku teks, buku apa yang digunakan?

Judul

Pengarang

Penerbit/Tahun Terbit:

Apabila buku teks yang digunakan lebih dari satu, silakan sebutkan.

9. Teknik/strategi pembelajaran apa yang sering digunakan dalam pembelajaran writing? (Sebutkan) .....................................................................................

10. Bagaimana respon siswa terhadap teknik/strategi pembelajaran writing tersebut? (beri tanda $x$ )
$\begin{array}{llll}\text { a. Sangat Baik } & \text { b. Baik } & \text { c. Kurang Baik } & \text { d. Tidak baik }\end{array}$

11. Apakah Bapak/Ibu pernah menerapkan teknik pembelajaran CIRC untuk mengajar writing di kelas? (beri tanda $x$ )

$$
\begin{array}{ll}
\text { a. Ya } & \text { b. Tidak }
\end{array}
$$

12. Bila Ya, darimana atau bagaimana Bapak/Ibu mengetahui teknik tersebut?

13. Seberapa jauh pemahaman Bapak/ibu tentang teknik pembelajaran tersebut?
a. Sangat paham b. Paham c. Kurang paham
d.Tidak paham

14. Bagaimana respon siswa terhadap pembelajaran writing dengan CIRC? (beri tanda $x$ )
a. Sangat Baik
b. Baik c. Kurang Baik
d. Tidak baik

15. Bagaimana hasil writing siswa dengan teknik CIRC? (beri tanda $x$ )
a. Sangat Baik
b. Baik
c. Kurang Baik
d. Tidak baik

16. Dalam pembelajaran writing menggunakan teknik CIRC, dibutuhkan sekurang-kurangnya........ kali pertemuan.

17. Apa saja kendala yang ditemui saat menerapkan CIRC di kelas? Jelaskan:

18. Apabila menggunakan CIRC dalam pembelajaran writing, apakah juga dilengkapi dengan buku panduan penggunaan? (beri tanda $x$ ) a. Ya b. Tidak

19. Bila tidak dilengkapi, apakah buku panduan tersebut diperlukan? (beri tanda $x$ )

20. Bila Ya,berikan alasan......

21. Apakah perlu adanya pengembangan Writing Guidelines menggunakan teknik CIRC? (beri tanda $x$ ) a. Ya

a. Ya b. Tidak Tidak

22. Bila Ya, berikan alasan:

Instrument of Questionnaire for the Teacher

\section{Appendix 2}

\section{KUESENER PENILAIAN TERHADAP KELAYAKAN BUKU PANDUAN WRITING MENGGUNAKAN METODE COOPERATIVE INTGRATED READING AND COMPOSITION (CIRC) UNTUK GURU BAHASA INGGRIS KELAS VIII}

\section{Nama Guru}

Di bawah ini kami sampaikan sejumlah pernyataan yang berkaitan dengan penggunaan buku panduan writing menggunakan metode CIRC di kelas anda. Berilah tanda centang $(\sqrt{ })$ pada pernyataan di bawah ini berdasarkan apa yang anda rasakan. Atas partisipasinya, kami ucapkan terimakasih.

Keterangan;

SS Sangat setuju

S Setuju

TS Tidak setuju

\begin{tabular}{|r|r|r|r|r|r|}
\hline \multicolumn{2}{|c|}{ STS Pangat tidak setuju } & SS & S & TS & STS \\
\hline No. & $\begin{array}{c}\text { Buku panduan ini dapat membantu } \\
\text { Buru untuk mencapai tujuan pembelajaran } \\
\text { menulis }\end{array}$ & & & & \\
\hline 2. & $\begin{array}{l}\text { Buku panduan ini dapat dijadikan } \\
\text { sebagai pedoman pengajaran writing }\end{array}$ & & & & \\
\hline
\end{tabular}




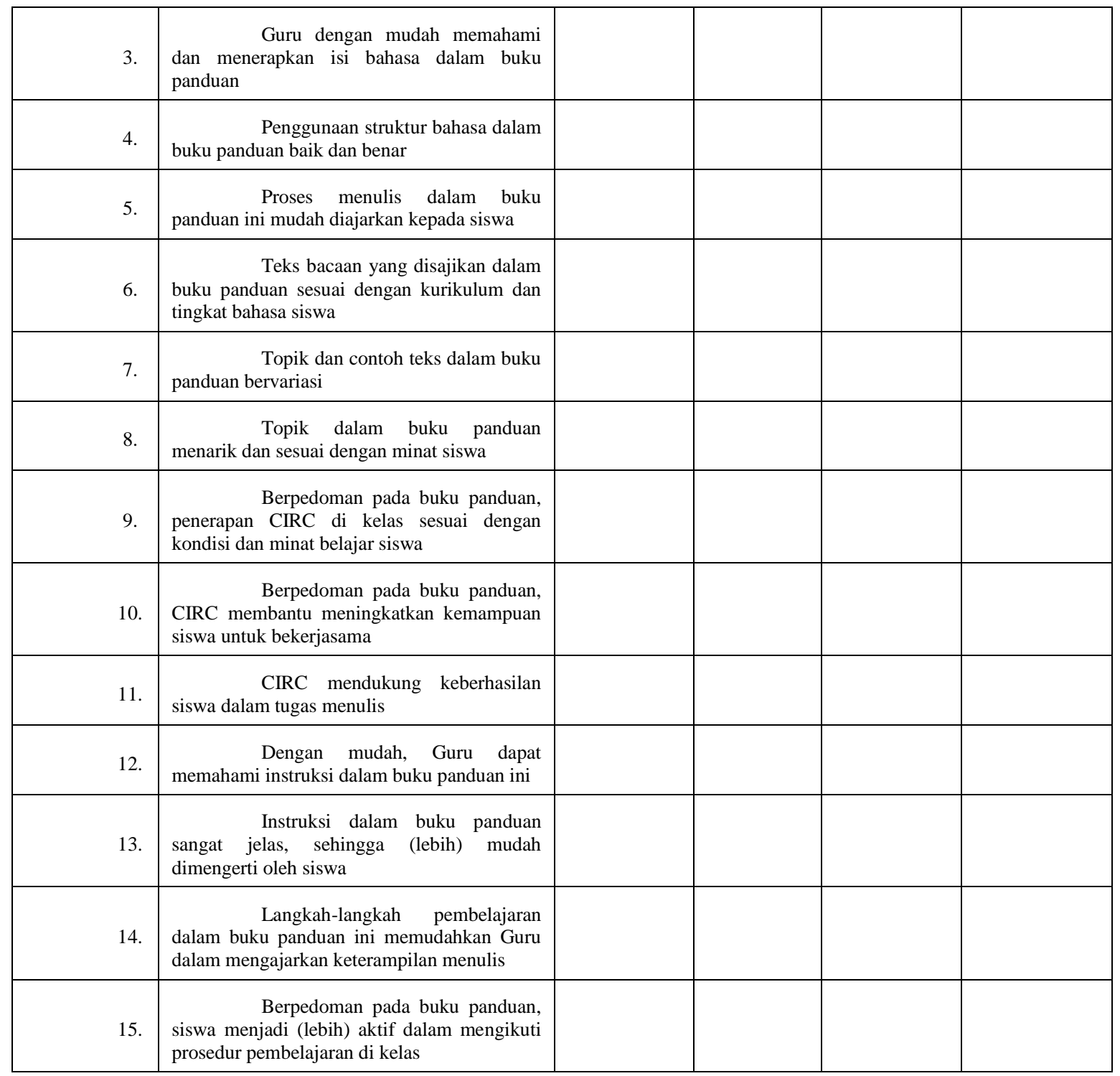

\section{Appendix 3}

\section{Instrument of Validation Form of Writing Guideline}

Title

Goal

: Validation Form of Writing Guideline Using CIRC

$: 1$. Measuring up the appropriateness of the product to be much more reliable.

2. Finding out the weaknesses of the product

3. Measuring up the feasibility of the product 
Rubrik Penilaian Guideline

\begin{tabular}{|c|c|c|}
\hline o. & Aspek & Kriteria \\
\hline \multirow{4}{*}{. } & \multirow{4}{*}{$\begin{array}{c}\text { Desain } \\
\text { (Design) }\end{array}$} & Sampul (cover) dan susunan (layout) buku panduan ini sangat menarik dan jelas \\
\hline & & Sampul (cover) dan susunan (layout) buku panduan ini cukup menarik dan jelas \\
\hline & & Sampul (cover) dan susunan (layout) buku panduan ini kurang menarik dan jelas \\
\hline & & Sampul (cover) dan susunan (layout) buku panduan ini tidak menarik dan jelas \\
\hline
\end{tabular}

Tujuan dari buku panduan ini tertulis sangat jelas dan sudah merepresentasikan seluruh isi dari buku panduan ini.

Tujuan dari buku panduan ini sudah tertulis jelas dan sudah merepresentasikan sebagian lebih isi dari buku panduan ini.

Tujuan

(Objektif)
Tujuan dari buku panduan ini tertulis kurang jelas dan merepresentasikan hanya sebagian isi dari buku panduan ini.

Tujuan dari buku panduan ini tertulis tidak jelas dan merepresentasikan hanya sedikit isi dari buku panduan ini.

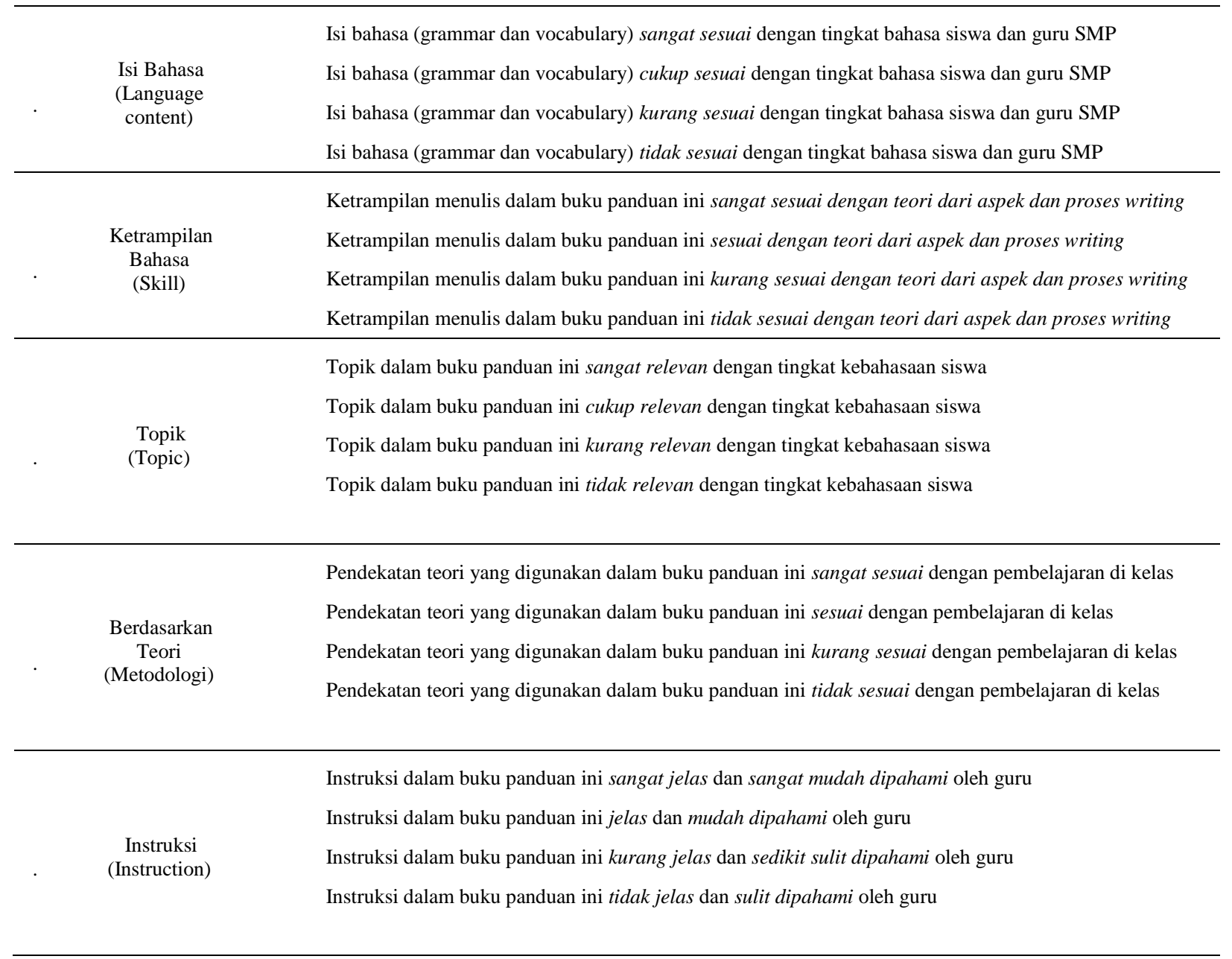




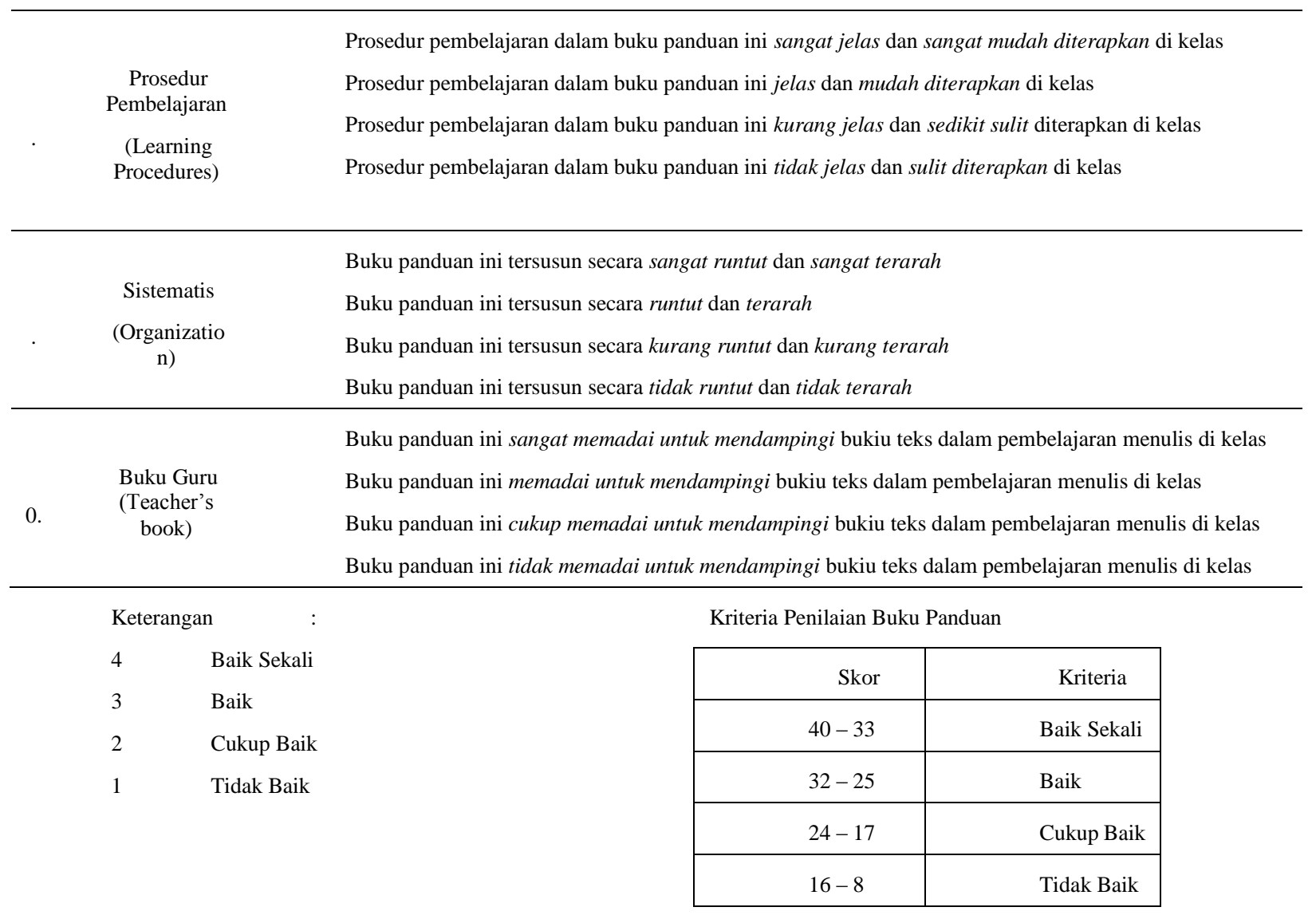

